\title{
SASTRA SEBELAH: PERLAKUKAN FILM SEBAGAI FILM!
}

\author{
Yoga Sudarisman \\ Dosen Luar Biasa Desain Komunikasi Visual 'Teori Film' \\ Universitas Telkom
}

\begin{abstract}
Abstrak
Akademisi sastra kadang banyak yang melihat film dengan sebelah mata. Maksud saya, perlakukan film layaknya film. Memang seperti halnya puisi, film disampaikan melalui pesan simbolis, majasi atau bahasa figuratif lainnya. Seperti halnya drama, film disampaikan melalui bahasa visual dan verbal. Seperti prosa, film juga sarat dengan elemen naratif. Namun tidak seperti genre sastra tersebut, film memiliki bahasa yang khas, yakni bahasa visual. Selain elemen naratif dan figuratif, film memiliki elemen sinematik atau bahasa visual yang menjadikannya perlu diperlakukan lebih dari pada genre sastra tertulis lainnya. Pada penelitian ini, Peneliti akan menyelisik keterkaitan naratif dan sinematik dalam film Sebelah (2011) karya Reza Rahadian melalui pendekatan tekstual dan genre. Bagaimana sisi naratif dan sisi sinematik secara bersama-sama mampu menyampaikan sebuah pesan dan membentuk tema genre.
\end{abstract}

\section{PENDAHULUAN}

Mengapa kita mempelajari

film? Pertanyaan ini sering dilontarkan oleh banyak kalangan, termasuk akademisi sastra. Sebagai pendahuluan, dengan melihat sifatnya, film itu dinamis. Ia bergerak dan berkembang seiring dengan kemajuan zaman dan teknologi. Namun demikian, mempelajari film bukan hanya persoalan dinamisnya (techinal) saja, peneliti sebaiknya memperhatikan semua aspek atau elemen yang dibawa oleh film, baik yang dibawa secara personal ataupun sosial yang terkandung dalam narasi. Sampai sini, tidak ada yang berbeda dengan sastra tertulis, bukan? Sastra tertulis juga selalu membawa pesan sosial dan budaya yang disisipkan dalam sebuah narasi.

Valerie Muller dalam The English Journal (2006) mencoba memvisualisasikan teori sastra dengan film. Teori naratif atau strukturalisme bisa dikaji dengan bahasa film. Sependapat dengan Muller, sudah saatnya akademisi sastra mengenal generasi baru dari sebuah teks yang sebetulnya sudah memiliki hubungan erat antara film dengan sastra. Teks yang sudah melekat (embedded) dalam sejarah film jauh sebelum perdebatan apakah film masuk ke dalam sastra atau bukan. Sifat film yang dinamis secara otomatis menjadikannya sebagai salah satu agen budaya seperti genre sastra lainnya - yang menyampaikan pesan-pesan simbolik dari sebuah budaya, namun kali ini dengan bahasa visual sebagai tambahan dalam teknik penyampaiannya.

Saya menganalogikan penulis (writer) atau pengarang (author) dalam menggunakan diksi pada karangan mereka dengan pembuat film yang memilih teknik pengambilan gambar pada produksi film mereka. Proses pemilihan kata 
(diksi) tersebut pasti didasari oleh sebuah intensi (author's intention) atau dengan kata lain ada unsur kesengajaan ketika seorang penulis memilih kata ini atau frasa itu. Begitu pun juga dengan teknik yang digunakan dalam memproduksi sebuah film. Peneliti perlu menyadari bahwa teknik yang digunakan oleh pembuat film membawa maksud atau pesan tertentu yang memungkinkan untuk diinterpretasikan sama halnya ketika menginterpretasikan ragam diksi tadi.

Yang ingin saya sampaikan di sini adalah pertama, sebuah film yang baik (lebih luas lagi untuk semua jenis video) akan selalu membawa makna, nilai dan pesan yang perlu diinterpretasikan dengan proses analisis. Boggs dan Petrie (2008: 8) mengungkapkan bahwa film yang baik adalah film yang dapat memunculkan kekaguman untuk menggali dan terus menggalinya dalam bingkai analisis. Kedua, kita harus sadar sepenuhnya dengan film yang sedang kita tonton. Dunia tidak akan cukup untuk dimasukkan dalam kotak berwarna 14 inch, 32 inch bahkan 60 inch. Gambar yang masuk ke dalam 'kotak sihir' bernama televisi di rumah kita adalah gambar pilihan yang sudah pasti membawa kekuatan magis (intensi) dari si pembuat film/video. Kita dituntut kritis dalam membaca atau menonton sesuatu.

Dalam bukunya The Art of Watching Films (2008), Boggs dan Petrie juga memberikan beberapa manfaat ketika kita melakukan proses analisis sebuah film. Salah satunya adalah dapat meningkatkan intuisi ke level sadar sampai akhirnya berada di level fokus untuk menggenggam makna/pesan dari film tersebut. Memang, pada akhirnya semua karya akan memunculkan interpretasi yang beragam terhadap karya yang sedang dibacanya dan tidak akan berakhir dengan jawaban pasti sekalipun dengan proses rasionalisasi. Namun, karya sastra dapat dijadikan solusi alternatif bagi setiap permasalahan sosial. Biasanya manusia akan menjadi tahu tentang kekurangannya ketika sedang becermin? dan mereka lebih tahu apa yang mesti dilakukan dengan kekurangan itu? Begitu pun juga karya sastra yang senantiasa menjadi cerminan fenomena sosial dan budaya baik terkait hal yang positif ataupun negatif.

Dengan tanpa mengurangi nilai seni dari sebuah film, proses analisis - sekali lagi - dapat membawa kita fokus dalam memahami pertanyaan penting yang bergelayut dalam ruang penasaran. Proses analisis film akan menjadi kebiasaan dan membebaskan pikiran kita dari pertanyaan-pertanyaan penting (atau mungkin sepele) tadi. Bahkan, kebiasaan tersebut akan membantu kita menyimpan sebuah 'pengalaman tersendiri' ketika menonton film.

\section{Kerangka Teoretis}

Dalam penelitian film, ada beberapa pendekatan yang dapat digunakan dalam membaca film. Saya merangkumnya ke dalam tiga pendekatan penting. Pertama adalah pendekatan text, atau textual analysis.

Textual analysis is a way for researchers to gather information about how other human beings make sense of the world. It is a methodology - a data-gathering process for those researchers who want to understand the ways in which members of various 
cultures and subcultures make sense of who they are, and of how they fit into the world in which they live (Allan McKee, 203: 1).

Penjelasan McKee di atas tentu berlaku pada semua penelitian termasuk dalam penelitian film, kajian media atau bahkan kajian budaya. Kita menafsirkan teks (sastra, film, fiksi, majalah, bahasa iklan, tagline kaos, grafiti, dan sebagainya) adalah cara kita untuk membuat semua fenomena yang terjadi di dunia ini masuk akal.

Kedua adalah analisis genre atau biasa dikenal dengan analisis formula. Cawelti (2001: 206-207) memberikan penjelasan bahwa genre adalah sebuah pola universal dan formula adalah sistem konvensi budaya atau dapat disimpulkan pola kultural. Saya beri contoh, sebagian besar orang paham dengan genre horor, atau genre yang dapat memunculkan ketakutan dan kadang memunculkan hantu. Namun hanya sebagian kecil dari mereka yang mengerti bahwa setiap budaya membawa pola mitos yang berbedabeda. Pocong adalah formula kultural yang muncul dalam budaya horor Indonesia, berbeda dengan Cina yang paham dengan mitos vampirnya, atau Eropa dengan drakulanya dan seterusnya seperti itu. Genre bersifat universal sedang formula lebih kultural.

Terakhir adalah analisis produksi. Pendekatan film dengan analisis produksi akan terkait dengan wujud film sebagai produk budaya populer yang tak lepas dari unsur Mass, Money dan Mechanism (Nachbar dan Lause, 1992: 12). Selain sisi industri dan ekonomi, analisis juga dapat meliputi transformasi film ke dalam novel atau sebaliknya.

Analisis pada penelitian ini akan didekati secara tekstual dan formulaik (genre). Melanjutkan usaha Muller untuk menjadikan bahasa visual populer di ranah sastra, proses menganalisis film sebagai film di sini akan sama seperti menganalisis sastra tertulis awalnya. Hanya saja sebagai tambahan, saya sadar bahwa ada sisi lain yang masih perlu digali, yakni mencari meaning dari cara pembuat film (filmmaker) dalam menggunakan teknik sinematik seperti penggunaan cahaya (lighting), sudut kamera (camera angle), memasang objek dalam bingkai (framing), gerak kamera (movement) dan proses editing. Perhatikan tabel bahasa visual di bawah ini: 
Table 1. Elemen Sinematik yang memungkinkan untuk memunculkan makna dan keterkaitannya dengan sastra/bahasa figuratif

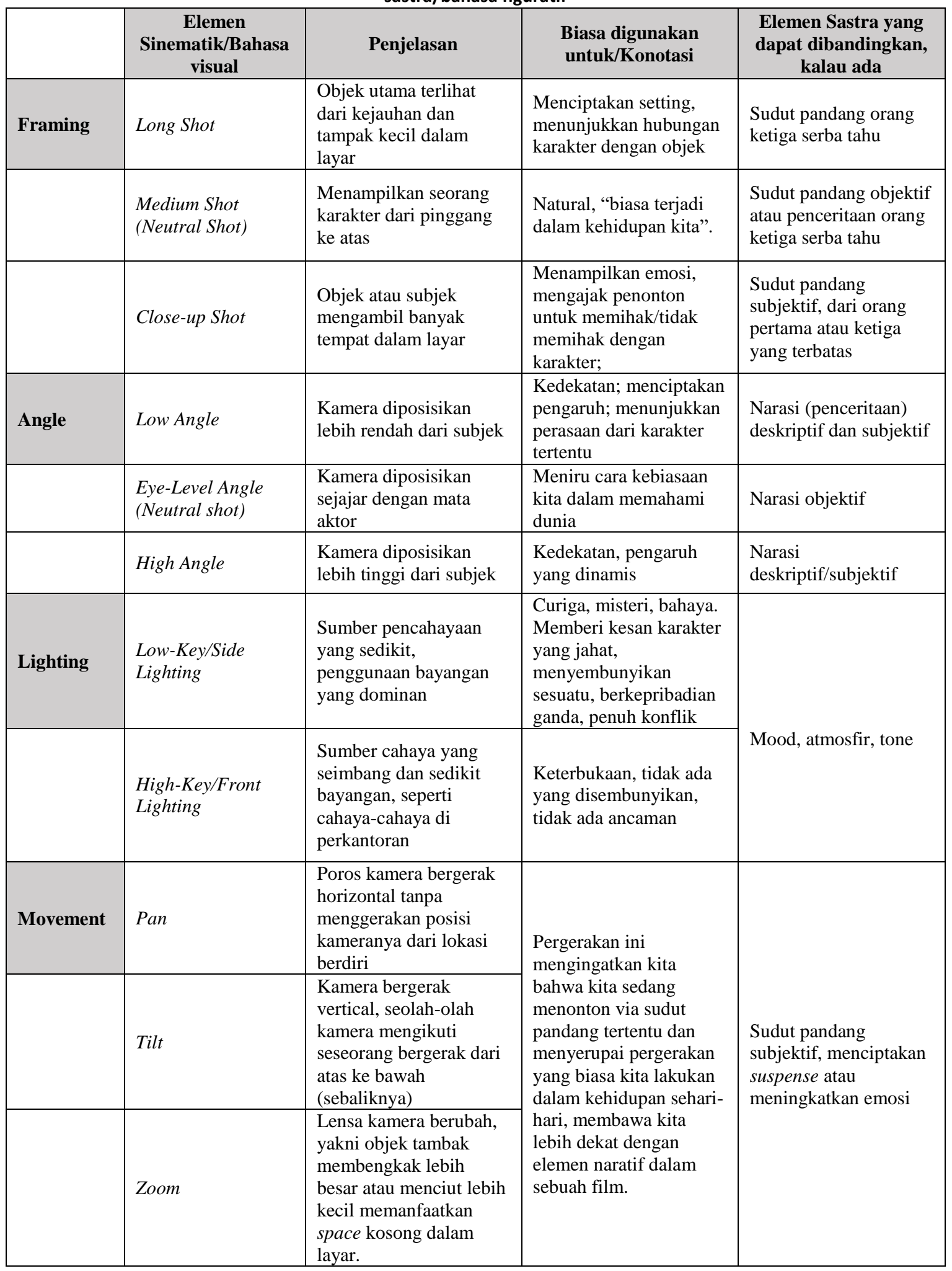




\begin{tabular}{|c|c|c|c|c|}
\hline & $\begin{array}{c}\text { Elemen } \\
\text { Sinematik/Bahasa } \\
\text { visual }\end{array}$ & Penjelasan & $\begin{array}{l}\text { Biasa digunakan } \\
\text { untuk/Konotasi }\end{array}$ & $\begin{array}{c}\text { Elemen Sastra yang } \\
\text { dapat dibandingkan, } \\
\text { kalau ada }\end{array}$ \\
\hline \multirow[t]{4}{*}{ Editing } & Fade & $\begin{array}{l}\text { "Gambar di layar secara } \\
\text { perlahan menghilang" } \\
\text { dan layar redup sampai } \\
\text { gamar selanjutnya } \\
\text { muncul. }\end{array}$ & \multirow[b]{2}{*}{$\begin{array}{l}\text { Adanya hubungan } \\
\text { antara dua objek atau } \\
\text { karakter dengan karakter }\end{array}$} & $\begin{array}{l}\text { Analogi, simile, } \\
\text { metafora, ironi, } \\
\text { penjajaran }\end{array}$ \\
\hline & Dissolve & $\begin{array}{l}\text { Satu gambar } \\
\text { menghilang (fade out) } \\
\text { disambut dengan } \\
\text { gambar selanjutnya } \\
\text { yang masuk (fade in), } \\
\text { jadi dua gambar muncul } \\
\text { secara singkat dalam } \\
\text { satu waktu }\end{array}$ & & $\begin{array}{l}\text { Mood, bisa } \\
\text { menciptakan ironi }\end{array}$ \\
\hline & Crosscut & $\begin{array}{l}\text { Disebut juga parallel } \\
\text { editing; sutradara } \\
\text { memotong antara dua } \\
\text { episode/gambar yang } \\
\text { berbeda }\end{array}$ & $\begin{array}{l}\text { Membentuk suspense } \\
\text { (ketegangan) }\end{array}$ & Tempo, langkah \\
\hline & Eyeline Match & $\begin{array}{l}\text { Dimulai dengan } \\
\text { pengambilan gambar } \\
\text { seorang tokoh melihat } \\
\text { pada satu arah, } \\
\text { diumpakan sedang } \\
\text { melihat sesuatu, } \\
\text { dipotong kepada objek } \\
\text { apapun yang sedang } \\
\text { dilihat tokoh, dan } \\
\text { dipotong lagi kepada } \\
\text { tokoh untuk melihat } \\
\text { reaksinya }\end{array}$ & $\begin{array}{l}\text { Memunculkan pikiran, } \\
\text { gagasan terhadap objek }\end{array}$ & Monolog \\
\hline
\end{tabular}

Sumber tabel: Muller, 2006: 34-35.

Teks asli dapat diakses melalui: https://www.jstor.org/stable/3004704 
Dari tabel di bahasa visual yang lagi dan lagi dipilih dengan maksud tertentu untuk keperluan narasi dalam menyampaikan pesan. Untuk lebih memudahkan

penjelasan tabel di atas, pada artikel ini, saya akan menganalisis film pendek indie ${ }^{1}$ Sebelah (2011) karya Reza Rahadian. Sebelah adalah film pemenang pada ajang festival film indie LA Lights atas, banyak mewakili analisis film dari sisi sastra Movie Award tahun 2012 dalam kategori "Bikin Film bareng Artis"2.

Ajang

film

franchise

yang diadakan oleh Los Angeles kini hadir di

berbagai negara termasuk Indonesia.

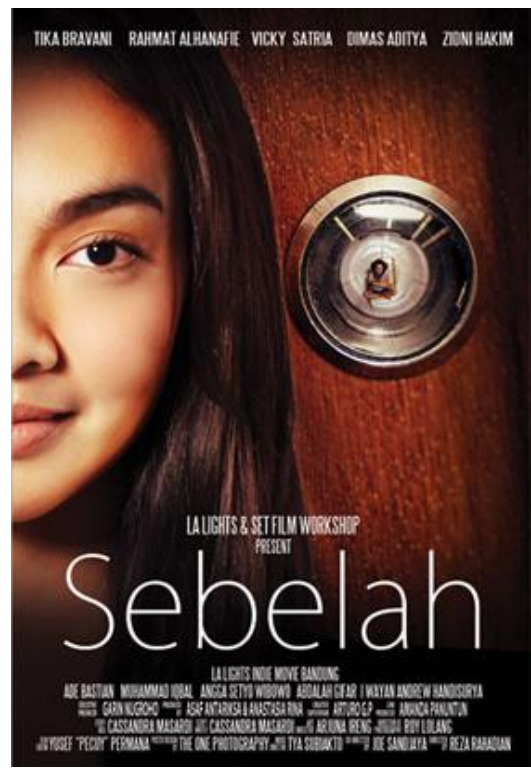

Gambar 1. Sampul film Sebelah secara padat dan komprehensif.

\section{PEMBAHASAN}

Film

ini berdurasi kurang lebih 15 menit. Alur pada film ini pun terbilang cukup mudah untuk diikuti sekalipun memasang alur majumundur. Suasana hati (mood) penonton menyeruak masuk ke ruang penasaran setelah menyadari adanya twistending (akhir yang menyimpan kejutan); mengapa tokoh wanita harus mengulang kesalahan yang sama? Apa yang sebenarnya terjadi?

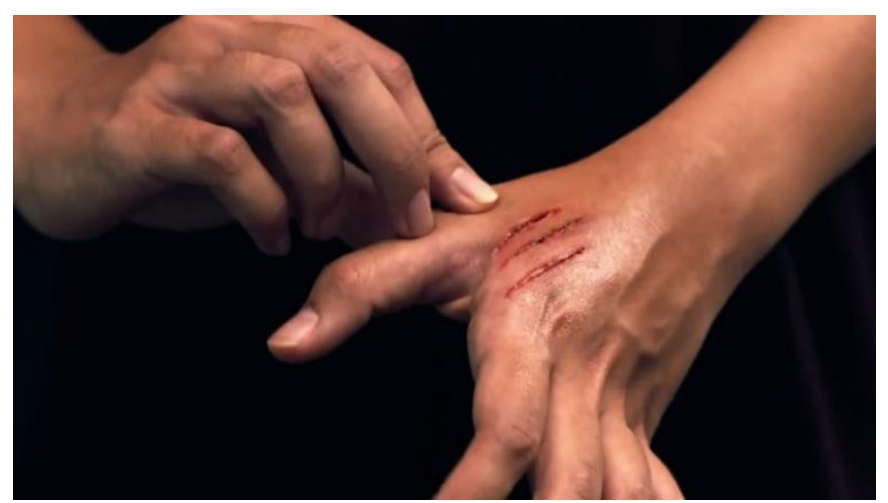

Gambar 2. Sumber film, menit 02:38

Siapa

sebenarnya

yang berperan antagonis?

Pada

penelitian ini, resensi narasi akan dijadikan objek analisis yang diharapkan mampu menjadi pola dalam

memasang standar LA Movie Awards, saya berharap analisis pada salah satu peraih penghargaan Best Movie film pendek ini dapat

\footnotetext{
${ }^{1}$ Film independen yang diproduksi di luar rumah produksi kenamaan atau dengan kata lain diproduksi dan didistribusikan dari dan untuk kalangan tertentu.

${ }^{2}$ Film dapat diakses di situs berbagi youtube:

https://www.youtube.com/watch?v=4wPx MmLk4Ag
}

mendekati film baik secara naratif ataupun sinematik. Film ini diawali dengan tokoh Delia (Tika Bravani) yang baru saja pindahan dan menjadi tetangga sebelah Fred (Alfie Alfandy) di sebuah apartemen. Kedekatan mereka dimulai ketika Fred melihat sebuah simbol aneh di tangan Delia. Bagi saya, simbol ini menjadi teknik pembuat film untuk 
memasang foreshadowing ${ }^{3}$ dalam narasinya. Penonton diharapkan akan lebih penasaran dengan narasi film sesaat setelah memasang simbol tersebut. Tidak hanya dengan simbol tadi, penonton terus dibuat penasaran dengan kedekatan mereka yang dibangun terlalu cepat hanya dengan Delia mempercayakan sebuah rahasia sepele pada Fred. Delia memelihara kucing di apartemen yang sebenarnya tidak boleh memelihara hewan peliharaan apapun. Simbol di tangannya adalah goresan luka berdarah - yang menurut pengakuan Delia tangannya dicakar kucing (gambar 2). Delia merasa berhutang pada Fred untuk sebuah rahasia sepelenya dan Fred meminta tolong Delia untuk menjadi pengisi suara pada proyek milik Fred sebagai pelunas utangnya. Karakterisasi tokoh Fred sebagai seorang editor suara pun tidak luput dari maksud si pembuat film dalam menyampaikan makna nantinya. Dalam sebuah plot, setiap tokoh akan dan selalu bertanggung jawab dengan penokohannya untuk bersama-sama memutarkan roda narasi.

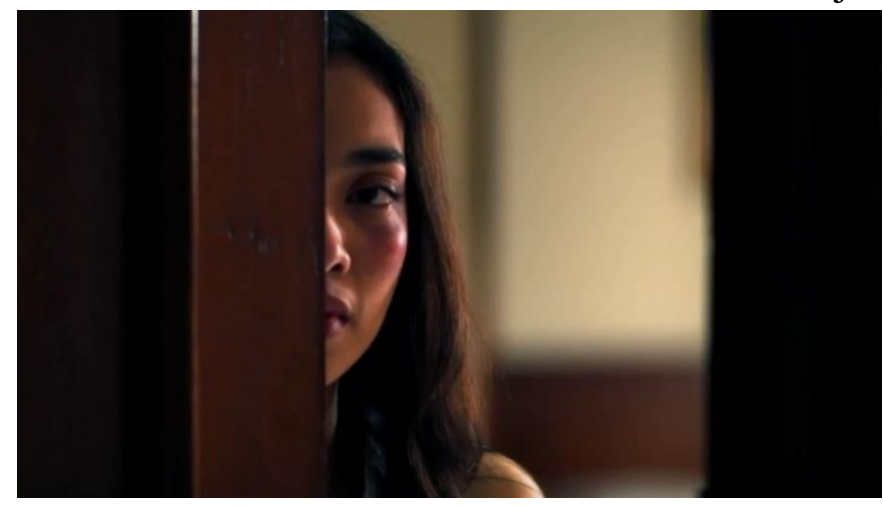

Gambar 3. Sumber film, menit 06:09

Sampai hari yang dijanjikan,

\footnotetext{
${ }^{3}$ petunjuk tentang sesuatu yang akan terjadi, antonim dari flashback: petunjuk dari masa lalu.
}

Delia tidak pernah keluar dari kamarnya. Fred tidak marah, justru ia berniat memberikan makanan kucing kaleng sebagai permintaan maafnya karena sudah melonjak meminta tolong pada tetangga yang baru pindahan. Lagi, di sini pembuat film memilih makanan kaleng kucing sebagai permintaan maaf Fred pada Delia yang sudah pasti bukan tanpa alasan. Pembuat film bermaksud ingin membawa cerita pada level selanjutnya tetap tidak keluar pada satu petunjuk yang saya katakan di awal akan ada kelanjutan dari foreshadowing cakaran kucing. Ketika pintu kamar Delia terbuka Fred menemukan kondisi Delia yang sudah berwajah memar dari balik pintu (gambar 3), seperti seseorang sudah memukulnya. Fred menduga Delia dipukuli kekasihnya. Delia memang tinggal berdua dengan kekasihnya. Pada adegan ini, pembuat film memberikan kesempatan pada penonton untuk menentukan genre apa sebenarnya film ini. Penonton/pembaca sudah dan akan melihat ada beberapa serpihan petunjuk yang seharusnya menjadi kunci utama dalam film ini.

Pertama dari judul film "Sebelah", penonton akan membaca makna yang lebih dari sekedar petunjuk arah sebelah. Dari sampul film, opening-credit dan sampai diulang dalam tengah adegan film menit ke 06:09 (gambar 3) memuat gambar seseorang dengan bentuk wajah sebelah. Beberapa interpretasi akan dimunculkan dengan pengambilan gambar yang kalau diperhatikan, menggunakan low-key lighting atau side-lighting (lihat tabel 1) dengan penjelasan sumber 
pencahayaan yang sedikit dan penggunaan bayangan (sisi gelap) yang dominan.

Pengambilan gambar dengan pencahayaan yang minim dapat dikonotasikan sebagai situasi yang penuh kecurigaaan, misteri, dan bahaya. Memberi kesan karakter yang jahat, menyembunyikan sesuatu, berkepribadian ganda atau penuh konflik. Beberapa aksi seperti terlihat pada gambar 5, sudah saatnya penonton dapat memahami apa yang sebenarnya dilakukan oleh Delia. Gambar 5 menjelaskan bahwa pengambilan gambar seperti ini

Gambar 4. Opening-Credit (adegan yang disimpan di awal film untuk menampilkan daftar anggota-anggota penting pada produksi sebuah film.

sedang mengintip Fred dari balik pintunya. Sampai sini, saya akan mengasosiasikan beberapa simbol

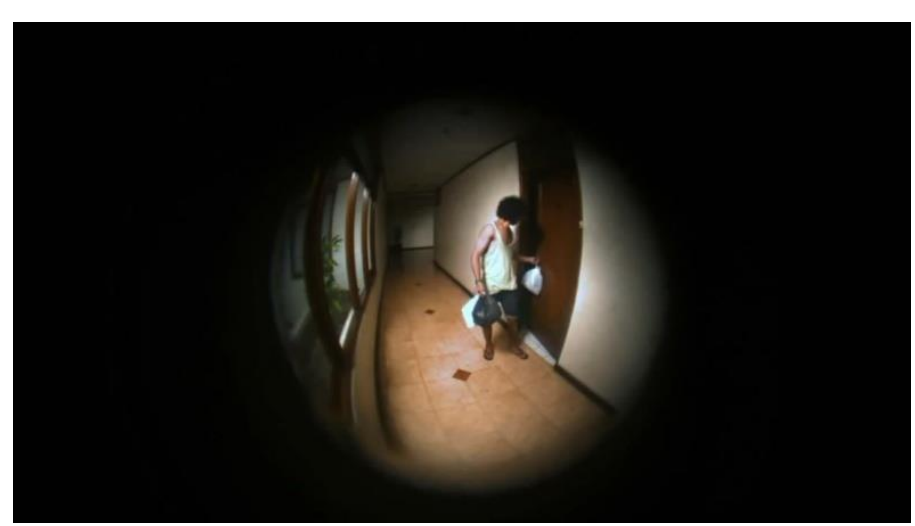
visual seperti tercantum di atas dengan karakteristik Delia yang misterius, penuh dengan tanda tanya dan mungkin berbahaya. Memang, simbol tidak selalu ada kaitan dengan yang disimbolkan. Seperti tidak ada kaitannya antara bunga mawar yang disimbolkan dengan rasa

Gambar 5. Sudut pandang subjektif (atau sudut pandang orang pertama tunggal), sumber film, menit 02:11

mengindikasikan adanya sudut pandang subjektif, dengan pergerakan kamera yang terlihat jauh (zoom out) namun penonton dapat dengan jelas menyaksikan apa yang sebenarnya terjadi dalam gambar seperti itu. Ada seseorang yang sedang mengintip. Gambar seperti ini biasanya digunakan juga ketika seseorang hendak memperhatikan dari sebuah teropong. Meskipun pembuat film hanya mewakilkan dengan pengambilan gambar dan cinta/romantis. Tapi dalam sastra, simbol memiliki tugas yang besar yakni sebagai representasi yang mendalam dari sebuah ide baik kultural ataupun universal. Seseorang dapat menyimbolkan cincin emas sebagai rasa cinta, tetapi dapat juga disimbolkan dengan seseorang yang terpenjara. Seperti warna putih yang dikaitkan dengan kebersihan, seperti itu juga hitam/gelap secara umum dikaitkan dengan sisi kejahatan. Itulah tugas simbol dalam sastra, sebagai media 
alternatif untuk menyampaikan

sesaat setelah mengetahui bahwa pesan-pesan budaya.

privasi sepele Delia tidak ingin

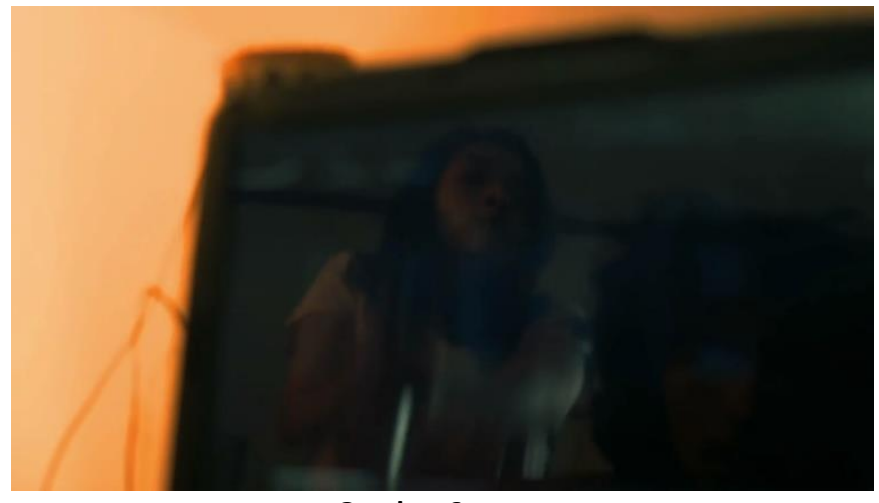

Gambar 6

Setelah saya simpan dalam ingatan tentang sosok Delia yang 'hitam kelam', formula yang mungkin awalnya seperti formula pada genre romantis: ada pertemuan yang saling beradu berakhir senyuman, bertanya tentang kesukaan satu sama lain, dan saling memegang rahasia/janji, kini ternyata formulanya berubah drastis menjadi formula genre misteri.

Level ketegangan semakin meningkat ketika Fred menemukan makanan kucingnya dibuang Delia ke tempat sampah. Gambar 6 lebih menjelaskan ada teka-teki dari Delia. Makanan kaleng kucing sama sekali tidak dibuka dan dibuang begitu saja. diketahui bahkan oleh tetangga yang sudah memegang rahasianya, Fred.

Fred : "Kamu ga punya kucing, kan? Кати ga pernah beli makanan kucing, ga ada suara kucing, ga pernah ada tanda-tanda kehidupan kucing di apartemen kamu."

Delia : "Kamu mata-matain $a k u ? "$

Fred : "Aku khawatir sama kamu. Siapa yang ngelakuin ini (bekas cakaran kucing dan memar di wajah), cowo kamu?!"

Delia : "Aku udah bilang aku jatuh." (sambil masuk ke dalam kamar)

Sumber: Sebelah (2011) menit 07:15 - 07:30

Dialog di atas mengungkapkan tentang genre misteri yang dengan pola dasar formulanya selalu berbagi teka-teki pada penonton/ pembacanya. Bahkan Delia seperti

Fred kesal, sebenarnya dari pertama mereka berjumpa dan melihat simbol cakaran kucing, Fred sudah merasa ada yang tidak beres. Cakaran kucing tidak mungkin separah dan sedalam itu dalam membuat luka. Pergerakan kamera membawa penonton pada ketegangan yang bisa dikatakan akan segera

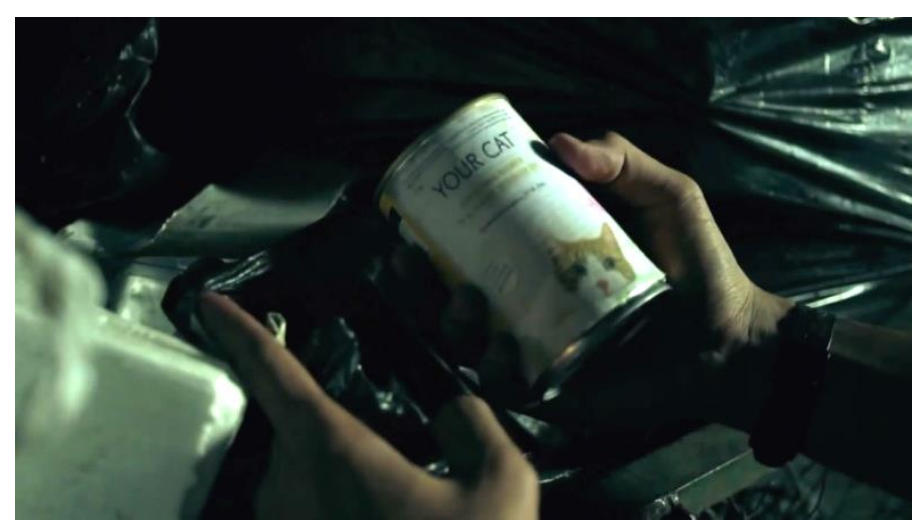
menuju puncak. Beberapa dialog di bawah menunjukkan bahwa mood penonton akan segera berubah
Gambar 8. sumber film, menit 12.23. Dari bayangan laptop, terlihat Delia membawa pisau untuk menikam Fred defensif dengan ucapan 'kamu matamatain aku?' Padahal penonton 
sudah sadar siapa sebenarnya yang selalu memata-matai.

Penonton berada pada adegan puncak di mana Fred sedang mencoba merekam proyek terbarunya sambil take vocal dengan mic masih menempel di bajunya, tiba-tiba Delia berteriak histeris dari kamarnya dan Fred langsung dengan cepat mendobrak pintu kamarnya. Ia dapati kekasihnya sedang mencekik leher Delia dengan sebilah pisau yang - entah bagaimana - tertancap di leher kekasihnya. Mengetahui kekasihnya masih mencekik Delia, Fred memukul laki-laki yang berlumuran darah itu sampai terkapar. Dengan segenap daya yang tersisa, kekasihnya menarik Fred lebih dekat sambil berucap sesuatu yang kurang jelas sebelum akhirnya ia mati.

Seketika genre misteri berubah lagi menjadi genre thriller (sesuatu yang mengerikan: pembunuhan). Karena di awal kedekatan mereka dibangun dengan saling menyimpan rahasia, setelah adegan pembunuhan itu pun, hubungan mereka menjadi lebih dekat karena kini mereka menjadi partner in crime (mitra kejahatan). Mereka kini mempunyai rahasia yang jauh lebih besar ketimbang seekor kucing. Namun secara perlahan, mereka dapat hidup bersama dan melupakan kejadian mengerikan yang pernah terjadi.

Sampai pada menit 11:20, Delia kembali menunjukkan simbol cakaran kucingnya pada tetangga barunya. Twist-ending sebentar lagi akan terasa: mengapa tokoh wanita harus mengulang kesalahan yang sama? Apa yang sebenarnya terjadi? Siapa sebenarnya yang berperan antagonis?

Karakterisasi tokoh Fred sebagai editor suara kini difungsikan. Sadar bahwa mic yang menempel di bajunya saat pembunuhan kekasih Delia masih menyala, ia berlari penasaran apa yang diucapkan kekasih Delia sebelum ia mati (lihat gambar 7). Seperti terlihat pada gambar 7, framing yang dipasang adalah close-up shot atau membuat subjek terlihat menghabiskan tempat di layar. Layar dipenuhi hanya oleh wajah subjek (Fred). Deskripsi semacam ini menampilkan emosi dan mengajak penonton untuk memihak atau tidak memihak dengan satu karakter (lihat tabel 1). Dengan pengambilan gambar close-up semacam ini, penonton akan memihak Fred dan dengan seksama ikut mendengarkan apa yang sebenarnya sedang didengar Fred.

Framing close-up seperti gambar 7 juga mempunyai arti dalam sastra sebagai sudut pandang subjektif, atau dari orang pertama

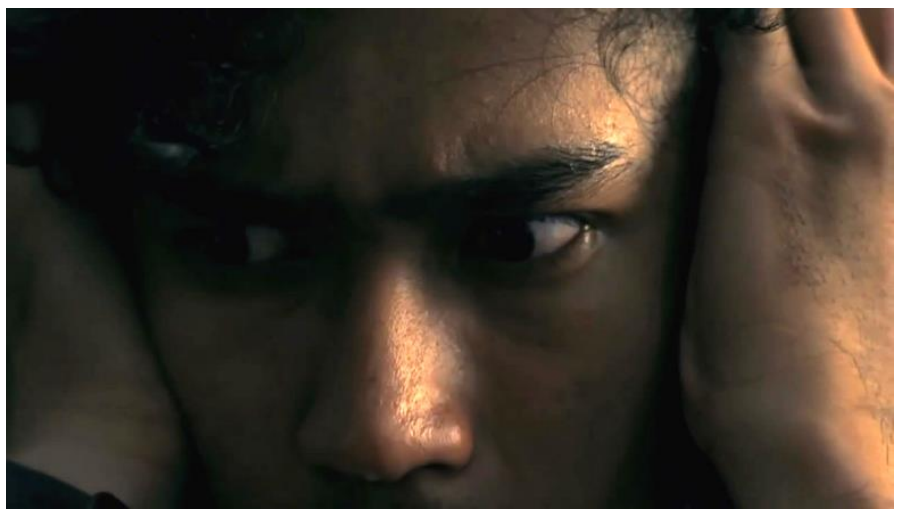

Gambar 7. sumber film, menit $\mathbf{1 2 . 1 3}$

dan terbatas, Fred tidak tahu bahwa ada seseorang dari belakang yang hendak melakukan sesuatu. Ketika sedang serius mendengarkan suara, seperti nasib kekasihnya, Fred pun ditikam Delia dari belakang dengan 
sebuah pisau (gambar 8). Cerita berakhir seperti sebelumnya. Dengan pisau menancap di leher, Fred mencekik Delia sampai berteriak histeris meminta tolong. Tetangga barunya datang, Fred pun dipukul sampai terkapar.

\section{KESIMPULAN}

Menonton adalah proses
membaca. Saya menyimpulkan
bahwa sebuah film dengan
bentuknya yang memadukan antara
elemen naratif dengan sinematik
menjadikannya perlu dibaca berbeda
dari karya tertulis lainnya. Tak hanya
unsur naratif (intrinsik), unsur
sinematik juga perlu dibaca sebagai
teks. Semua elemen dalam film
memuat pesan dan maksud tertentu.
Sebelah (2011) adalah salah satu
contoh film yang dijadikan bahan
analisis dengan pendekatan tekstual
dan genre. Penelitian ini hanya
memaparkan keterkaitan antara
bahasa sinematik dan naratif dalam
membentuk genre pada film.
Beberapa baris dialog (naratif) juga
potongan gambar (sinematik)
menjadikan genre sebelah berubah
dari yang mulanya terkesan romantis,
menit-menit terakhir berganti
menjadi genre misteri dan thriller.

\section{DAFTAR PUSTAKA}

Boggs, Joseph M. and Dennis W. Petrie. The Art of Watching Films. New York: McGraw-Hill, 2008.

Cawelti, John. G. "The Concept of Formula in the Study of Popular Literature." Popular Culture. Production and Consumption (2001): 203-209.

McKee, Alan. Textual Analysis: A Beginner's Guide. London: SAGE Publications Ltd., 2003.
Muller, Valerie. "Film as Film: Using Movies to Help Students Visualize Literary Theory." The English Journal (2003): 32-38.

Silverblatt, Art. Genre Studies in Mass Media A Handbook. New York: M.E. Sharpe, Inc., 2007. 
Jurnal al-Tsaqafa Volume 13, No. 02, Juli 2016

8

Halaman ini sengaja dikosongkan 